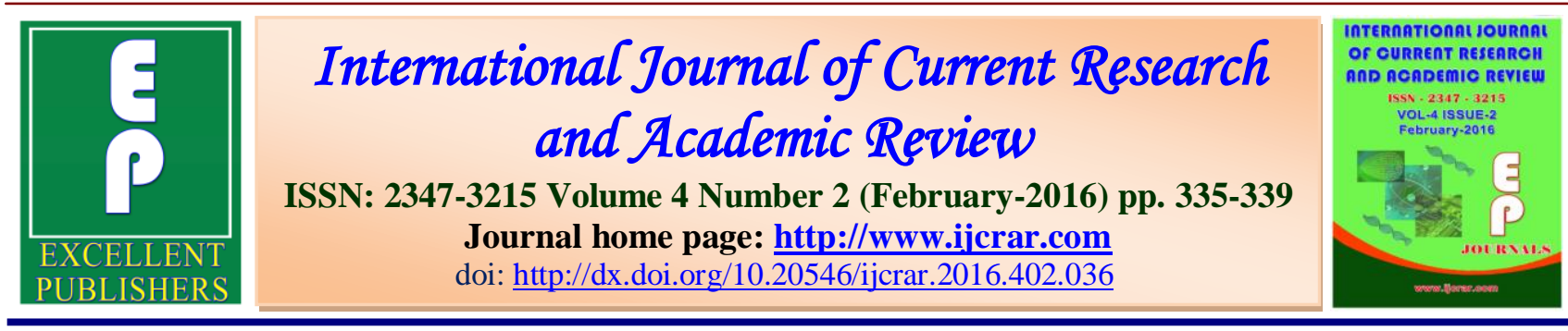

\title{
Standardization of Surface Sterilization Technique for In-vitro Propagation of Anthurium (Anthurium andraeanum Lind.) cv. Jewel
}

\section{Rocky Thokchom* and Soumen Maitra}

Department of Floriculture, Medicinal and Aromatic Plants, Faculty of Horticulture, Uttar Banga Krishi Viswavidyalaya, Pundibari, Cooch Behar - 736165, West Bengal, India

*Corresponding author

\begin{tabular}{|c|c|}
\hline KEYWORDS & A B S T R A C T \\
\hline $\begin{array}{l}\text { Anthurium, } \\
\text { Contamination, } \\
\text { explant, } \\
\text { In vitro, } \\
\text { Sterilization } \\
\text { procedure }\end{array}$ & $\begin{array}{l}\text { An experiment was conducted to standardize the surface sterilization } \\
\text { technique of Anthurium andraeanum cv. Jewel using immature bronze } \\
\text { coloured leaves as explants for callus induction. Explants were collected, } \\
\text { cleaned repeatedly using Tween- } 20 \text { in fresh running water and then treated } \\
\text { with } 12 \text { different combinations of Sodium hypochlorite }(1.5 \%) \text {, Mercuric } \\
\text { chloride }(0.1 \%) \text { and ethyl alcohol }(70 \%) \text { with varying exposure durations. } \\
\text { Surface-sterilized explants were then inoculated in MS medium supplemented } \\
\text { with various concentrations and combinations of } 2,4-\mathrm{D} \text {, BAP and TDZ. Leaf } \\
\text { explants when treated with mercuric chloride }(0.1 \%) \text { ( } 3 \text { minutes) + ethyl } \\
\text { alcohol ( } 70 \%) \text { ( } 30 \text { seconds) resulted in lowest percentage }(3.67) \text { of } \\
\text { contaminated cultures, lowest explant mortality }(11.33 \%) \text { as well as highest } \\
\text { survivability }(85.67 \%) \text {. Sodium hypochlorite }(1.5 \%)(15 \text { minutes) resulted in } \\
\text { highest explant mortality ( } 49.33 \%) \text { while } 5 \text { minutes treatment resulted in } \\
\text { lowest survivability ( } 30.33 \%) \text {. Mercuric chloride }(0.1 \%)(3 \text { minutes) + ethyl } \\
\text { alcohol ( } 70 \%)(30 \text { seconds) may be recommended for micropropagation of } \\
\text { Anthurium through leaf explants. }\end{array}$ \\
\hline
\end{tabular}

\section{Introduction}

Anthurium andraeanum is one of the important potted and cut flower ornamentals in the world. They are highly prized for its attractive, long lasting flowers. In the global market, Anthurium stands second after orchid among the tropical cut flowers (Dufour and Guerin, 2003). Three conventional methods for Anthurium production are propagation by seeds, traditional propagation method and tissue culture. Conventional vegetative propagation of Anthurium by separating the newly developing plants is time consuming and it takes years to develop commercial quantities of elite clones (Harb et al., 2010). The conventional propagation in the field has also faced some constraints due to disease attacks like involvement of Erwinia 
caratovora and Dasheen Mosaic virus (DMV) (Budiarto, 2008). To produce disease free clones and rapid production of quality plantlets, in vitro propagation is the only best method (Martin et. al, 2003; Çimen and Ozge, 2009; Raad et. al, 2012). The successful in vitro propagation using young leaf explant to reduce contamination and oxidative browning of explants consists of various stages. The steps consist of selection of explants, aseptic culture establishment, multiplication, rooting and acclimatization of plants (Budiarto and Handayati, 2007). For a successful and efficient micro propagation method, it is efficient to start with an efficient plant material sterilization step (Traore et al., 2005). Successful tissue culture of all plant species depends on the removal of exogenous and endogenous contaminating microorganisms (Buckley and Reed, 1994). To eliminate contamination during in vitro propagation different methods have been developed (Hussain et al., 1994; Herman, 1996). In vitro contamination by fungi, bacteria and yeast is one of the most serious problems of commercial and research plant tissue laboratories. Contaminated plants can reduce multiplication and rooting rates or may die. It is necessary to remove foreign contaminants including bacteria and fungi from explants and it is very difficult to obtain sterile plant material completely free from contamination (Mihaljevic et al., 2013). Surface sterilization of the naturally contaminated living plant materials from the environment is a critical step since it involves the use of chemical solutions like sodium hypochlorite, ethanol, mercuric chloride etc. that are toxic to the plant tissues (George, 1993).

The procedure of sterilization depends on plant species and explant taken from the plant for sterilization. Each plant material has variable surface contaminant levels, depending on the growth environment, age and part of the plant used for micropropagation (Mihaljevic et al., 2013). To avoid the problems of microbial contamination in in-vitro cultures, it is necessary to develop a protocol for disinfecting the field grown explants intended for in vitro culture. Keeping this in view, an efficient and simple disinfection protocol to increase survival of explants was developed.

\section{Materials and Methods}

The experiment was conducted at plant tissue culture laboratory, Department of Floriculture, Medicinal and Aromatic Plants, UBKV, Cooch Behar during January 2014 and February 2014. Immature bronze coloured leaf explants were collected from the net house of the department. Before sterilization, the explants were washed thoroughly under running tap water using 23 drops of Tween-20 detergent for about 20 minutes then rinsed with water for 4-5 times. After washing, the explants were reduced in size by removing tissues of size $(0.5-1.0 \mathrm{~cm})$ with the help of surgical blade and forceps before inoculation. The washed explants were then brought to laminar flow cabinet and were subjected to surface sterilization. The explants were subjected to different sterilants and their combinations for varying time durations as shown in Table 1, followed by a 5 minutes rinse in sterile distilled water under aseptic conditions in the laminar flow chamber. Before starting the work, the table surface of laminar flow cabinet was first swabbed with $95 \%$ ethanol and all the required materials except the excised explants were kept inside the chamber and exposed to UV light for 60 min. The laminar flow was switched on 10 min prior to inoculation. The explants were then put on Murashige and Skoog (MS) medium supplemented with $30 \mathrm{~g} / \mathrm{l}$ sucrose, vitamins, agar (7 g/l) and appropriate plant hormones such as 2,4-D (2 mg/l), BAP (0.5 
$\mathrm{mg} / \mathrm{l})$ and TDZ (0.1 mg/l) with $\mathrm{pH}$ adjusted to 5.8 before autoclaving the media at $121^{\circ} \mathrm{C}$ and $1.5 \mathrm{~atm}$. for 15 minutes. The explants were placed in such a manner that conformed to the original polarity and exposed above the surface of growing medium.

The cultures were then kept in a growth chamber for about three weeks at $25 \pm 2^{\circ} \mathrm{C}$ with 16 hours photoperiod and 3500 lux of light intensity. After three weeks of inoculation, the percentage of contaminated, dead and survived explants was recorded. Ten explants were used in each sterilization treatment and each treatment was done in 3 replications. The data generated was subjected to ANOVA in complete randomized design at 5\% level of significance. To satisfy model, assumptions of experiments were subjected to square root transformations.

\section{Results and Discussion}

Anthurium explants (bronze coloured immature leaves) were subjected to 12 different sterilization regimes using MS (Murashige and Skoog, 1962) as the basal medium. Effect on various sterilants used on explants on contamination, death and survival of the explants (Table 2) was highly significant. Lowest contamination percentage (3.67) was obtained by treating the explants in mercuric chloride $(0.1 \%)$ for $3 \mathrm{~min}+$ ethyl alcohol (70\%) for $30 \mathrm{~s}$ as well as in mercuric chloride $(0.1 \%)$ for $4 \mathrm{~min}+$ ethyl alcohol (70\%) for $30 \mathrm{~s}$. However, the lowest mortality percentage (11.33) and highest survivability percentage (85.67) was obtained when explants were surface sterilized with mercuric chloride $(0.1 \%)$ for 3 min + ethyl alcohol $(70 \%)$ for $30 \mathrm{~s}$.

Though less percentage of contaminated cultures was obtained in mercuric chloride $(0.1 \%)$ for 4 min + ethyl alcohol $(70 \%)$ for $30 \mathrm{~s}$, the surviving percent was less as a result of necrosis and tissue injury of explants (Jan et al., 2013). Highest contamination percentage (39.33) and lowest survivability percentage (30.33) was obtained when the explants were treated with Sodium hypochlorite (1.5\%) for $5 \mathrm{~min}$.

Table.1 Different Sterilants and their Combination for Varying Time Duration

\begin{tabular}{|l|l|}
\hline Sterilants and their combination & Time duration \\
\hline Mercuric chloride $(0.1 \%)$ & $2 \mathrm{~min}$ \\
\hline Mercuric chloride $(0.1 \%)$ & $3 \mathrm{~min}$ \\
\hline Mercuric chloride $(0.1 \%)$ & $4 \mathrm{~min}$ \\
\hline Sodium hypochlorite $(1.5 \%)$ & $5 \mathrm{~min}$ \\
\hline Sodium hypochlorite $(1.5 \%)$ & $10 \mathrm{~min}$ \\
\hline Sodium hypochlorite $(1.5 \%)$ & $15 \mathrm{~min}$ \\
\hline Mercuric chloride $(0.1 \%)+$ ethyl alcohol $(70 \%)$ & $2 \mathrm{~min}+30 \mathrm{~s}$ \\
\hline Mercuric chloride $(0.1 \%)+$ ethyl alcohol $(70 \%)$ & $3 \mathrm{~min}+30 \mathrm{~s}$ \\
\hline Mercuric chloride $(0.1 \%)+$ ethyl alcohol $(70 \%)$ & $4 \mathrm{~min}+30 \mathrm{~s}$ \\
\hline Sodium hypochlorite $(1.5 \%)+$ ethyl alcohol $(70 \%)$ & $5 \mathrm{~min}+30 \mathrm{~s}$ \\
\hline Sodium hypochlorite $(1.5 \%)+$ ethyl alcohol $(70 \%)$ & $10 \mathrm{~min}+30 \mathrm{~s}$ \\
\hline Sodium hypochlorite $(1.5 \%)+$ ethyl alcohol $(70 \%)$ & $15 \mathrm{~min}+30 \mathrm{~s}$ \\
\hline
\end{tabular}


Int.J.Curr.Res.Aca.Rev.2016; 4(2): 335-339

Table.2 Influence of Different Sterilants on Percent Contaminated, Death and Survivability of Cultures in Anthurium andraeanum cv. Jewel

\begin{tabular}{|c|c|c|c|}
\hline Time duration & Contaminated & Death & Survival \\
\hline Mercuric chloride $(0.1 \%)(2 \mathrm{~min})$ & $\begin{array}{c}27.00 \\
(31.30) \pm 1.11\end{array}$ & $\begin{array}{c}29.67 \\
(33.00) \pm 0.96\end{array}$ & $\begin{array}{c}43.33 \\
(41.16) \pm 1.77\end{array}$ \\
\hline Mercuric chloride $(0.1 \%)(3 \mathrm{~min})$ & $\begin{array}{c}12.67 \\
(20.78) \pm 2.20\end{array}$ & $\begin{array}{c}12.33 \\
(20.54) \pm 1.32\end{array}$ & $\begin{array}{c}75.00 \\
(60.04) \pm 2.37\end{array}$ \\
\hline Mercuric chloride $(0.1 \%)$ (4 min) & $\begin{array}{c}5.33 \\
(13.27) \pm 1.92\end{array}$ & $\begin{array}{c}36.33 \\
(37.07) \pm 0.91\end{array}$ & $\begin{array}{c}58.33 \\
(49.80) \pm 0.89\end{array}$ \\
\hline Sodium hypochlorite (1.5\%) (5 min) & $\begin{array}{c}39.33 \\
(38.84) \pm 0.90 \\
\end{array}$ & $\begin{array}{c}30.33 \\
(33.41) \pm 0.95\end{array}$ & $\begin{array}{c}30.33 \\
(33.41) \pm 0.95 \\
\end{array}$ \\
\hline Sodium hypochlorite (1.5\%) (10 min) & $\begin{array}{c}19.33 \\
(26.07) \pm 0.84\end{array}$ & $\begin{array}{c}19.00 \\
(25.82) \pm 1.46\end{array}$ & $\begin{array}{c}60.67 \\
(51.16) \pm 1.22 \\
\end{array}$ \\
\hline Sodium hypochlorite (1.5\%) (15 min) & $\begin{array}{c}9.33 \\
(17.69) \pm 2.47\end{array}$ & $\begin{array}{c}49.33 \\
(44.62) \pm 2.02 \\
\end{array}$ & $\begin{array}{c}41.33 \\
(40.01) \pm 0.68 \\
\end{array}$ \\
\hline $\begin{array}{l}\text { Mercuric chloride }(0.1 \%)+\text { ethyl } \\
\text { alcohol }(70 \%)(2 \min +30 \mathrm{~s})\end{array}$ & $\begin{array}{c}22.67 \\
(26.76) \pm 3.35\end{array}$ & $\begin{array}{c}16.67 \\
(24.08) \pm 1.18\end{array}$ & $\begin{array}{c}60.67 \\
(51.16) \pm 1.22\end{array}$ \\
\hline $\begin{array}{l}\text { Mercuric chloride }(0.1 \%)+\text { ethyl } \\
\text { alcohol }(70 \%)(3 \min +30 \mathrm{~s})\end{array}$ & $\begin{array}{c}3.67 \\
(10.95) \pm 1.70\end{array}$ & $\begin{array}{c}11.33 \\
(19.64) \pm 1.37\end{array}$ & $\begin{array}{c}85.67 \\
(67.77) \pm 1.24\end{array}$ \\
\hline $\begin{array}{l}\text { Mercuric chloride }(0.1 \%)+\text { ethyl } \\
\text { alcohol }(70 \%)(4 \min +30 \mathrm{~s})\end{array}$ & $\begin{array}{c}3.67 \\
(11.02) \pm 0.91\end{array}$ & $\begin{array}{c}45.67 \\
(42.51) \pm 1.20\end{array}$ & $\begin{array}{c}50.67 \\
(45.38) \pm 1.33\end{array}$ \\
\hline $\begin{array}{l}\text { Sodium hypochlorite }(1.5 \%)+\text { ethyl } \\
\text { alcohol }(70 \%)(5 \mathrm{~min}+30 \mathrm{~s})\end{array}$ & $\begin{array}{c}31.33 \\
(34.03) \pm 1.55\end{array}$ & $\begin{array}{c}22.00 \\
(27.95) \pm 1.39\end{array}$ & $\begin{array}{c}46.67 \\
(43.09) \pm 1.45\end{array}$ \\
\hline $\begin{array}{l}\text { Sodium hypochlorite }(1.5 \%)+\text { ethyl } \\
\text { alcohol }(70 \%)(10 \mathrm{~min}+30 \mathrm{~s})\end{array}$ & $\begin{array}{c}8.00 \\
(16.35) \pm 2.13\end{array}$ & $\begin{array}{c}18.00 \\
(25.05) \pm 2.24\end{array}$ & $\begin{array}{c}74.00 \\
(59.36) \pm 1.74\end{array}$ \\
\hline $\begin{array}{l}\text { Sodium hypochlorite }(1.5 \%)+\text { ethyl } \\
\text { alcohol }(70 \%)(15 \mathrm{~min}+30 \mathrm{~s})\end{array}$ & $\begin{array}{c}7.33 \\
(15.60) \pm 2.38\end{array}$ & $\begin{array}{c}21.33 \\
(27.49) \pm 1.47\end{array}$ & $\begin{array}{c}71.00 \\
(57.44) \pm 2.17\end{array}$ \\
\hline S.Em \pm & 1.00 & 0.73 & 0.61 \\
\hline $\mathrm{CD}$ at $5 \%$ & 2.93 & 2.14 & 1.78 \\
\hline
\end{tabular}

This might be the result of weaker chemical effect due to shorter exposure duration that unable to kill the pathogens present in the explant. Highest mortality percentage was obtained when the explants were treated with Sodium hypochlorite $(1.5 \%)$ for 15 min. This may be due to the fact that longer exposure duration damages the explant tissues and ultimately dries out after becoming necrotic.

\section{Conclusion}

Among the several sterilization techniques followed, the lowest contamination percentage were achieved when the explants were treated with mercuric chloride $(0.1 \%)$ for $3 \mathrm{~min}+$ ethyl alcohol $(70 \%)$ for $30 \mathrm{~s}$ and as well as mercuric chloride $(0.1 \%)$ for 4 min + ethyl alcohol $(70 \%)$ for $30 \mathrm{~s}$ but the mortality percentage was much higher than the previous due to higher necrotic cultures. Overall, the highest explant survival and the lowest mortality percentage were observed in the previous treatment. So it is concluded from the above study that sterilization treatment of mercuric chloride $(0.1 \%)$ for 3 min and ethyl alcohol $(70 \%)$ for $30 \mathrm{~s}$ is effective for field grown anthurium leaf explants intended for in vitro culture.

\section{References}

Buckley, P.M. and Reed, B.M. (1994): Antibiotic susceptibility of plant associated bacteria. Hort. Sci., 29:434. 
Budiarto, K. (2005). Micro propagation of several potted anthurium accessions using spathe explants. Jurnal Natur Indonesia, 11(1): 59-63.

Budiarto, K. and Handayati, W. (2007). In vitro propagation of several anthurium accessions using leaf explants. AGRIVITA, 39(3): 261 - 268.

Çimen, A. and Özge, C. (2009). Micropropagation of Anthurium andraeanum from leaf explants. Pakistan Journal of Botany, 41(3): 1155-1161.

Dufour, L. and Guerin, V. (2003). Growth, developmental features and flower production of Anthurium andraeanum Lind. in tropical condition. Scientia Horticulturae, 98 25-35.

George, F. (1993). Plant propagation by tissue culture. Exergetics Ltd., Edington, England.

Herman, E.B. (1996): Microbial contamination of plant tissue cultures. Agritech Consultants Inc, Shrub Oak, USA.

Hussain, S.; Lane, S.D. and Lane, D.N. (1994): A preliminary evaluation of the use of microbial culture filtrates for the control of contaminants in plant tissue culture systems. Plant Cell Tiss. Organ Cult., 36:45-51.

Harb, E.M., Talaat, N.B., Weheeda, B.M., El-Shamy, M., Omira, G.A. (2010). Micropropagation of Anthurium andreanum from shoot tip explants. Journal of Applied Sciences Research, 6(8) 927-931.

Jan, A.; Bhat, K.M.; Bhat, S.J.A.; Mir, M.A.; Bhat, M.A.; Imtiyaz A.;Wani and Rather, J.A. (2013). Surface sterilization method for reducing microbial contamination of field grown strawberry explants intended for in vitro culture. African Journal of Biotechnology, 12(39): 5749-5753.

Martin, K.P.; Joseph, D.; Madassery, J. and Philip, V.J. (2003). Direct shoot regeneration from lamina explants of two commercial cut flower cultivars of Anthurium andreanum Hort. In Vitro Cell. Dev. Biol-Plant, 39: 500-504.

Mihaljević, I.; Dugalić, K.; Tomaš, V.; Viljevac, M.; Pranjić, A.; Čmelik Z.; Puškar, B. and Jurković, Z. (2013) In vitro sterilization procedures for micropropagation of 'Oblačinska' sour cherry. Journal of Agricultural Sciences, 58(2): 117-126.

Murashige, T. and Skoog, F. (1962). A revised medium for rapid growth and bio-assays with tobacco tissue cultures. Physiologica Plantarum, 15: 473-497.

Raad, M.K.; Zanjani, S.B.; Shoor, M.; Hamidoghli, Y.; Sayyad, A.R.; Masouleh, A.K. and Kaviani, B. (2012). Callus induction and organogenesis capacity from lamina and petiole explants of Anthurium andraeanumLinden (Casino and Antadra). Australian Journal of Crop Science, 6(5): 928-937.

Traore, A.; Xing, Z.; Bonser, A. and Carlson, J. (2005). Optimizing a protocol for sterilization and in vitro establishment of vegetative buds from immature Douglas fir trees. Hort Science, 40(5): 1464-1468.

\section{How to cite this article:}

Rocky Thokchom and Soumen Maitra. 2016. Standardization of Surface Sterilization Technique for In-vitro Propagation of Anthurium (Anthurium andraeanum Lind.) cv. Jewel. Int.J.Curr.Res.Aca.Rev. 2016.4(2): 335-339.

doi: http://dx.doi.org/10.20546/ijcrar.2016.402.036 